\title{
MID-HOLOCENE GULLYING INDICATING EXTREME HYDROCLIMATIC EVENTS IN THE CENTRE OF THE RUSSIAN PLAIN
}

\author{
ANDREY PANIN, YULIA FUZEINA, INESSA KAREVSKAYA, ELENA SHEREMETSKAYA \\ Faculty of Geography, Lomonosov Moscow State University \\ Lengory 1, Moscow, 119991, Russia \\ E-mail: a.v.panin@yandex.ru
}

\begin{abstract}
At the Satino site in the center of the Russian Plain, major events of the Holocene erosion history are concentrated on sides of river valleys incised into smooth moraine landscape. Valley sides are dissected by Pleistocene gullies. Extraordinary for the Holocene was formation of four new permanent gullies. Three of them had appeared in the Late Atlantic - Early Subboreal time. One gully permitted direct dating of the fan base, which gave estimation of its appearance between 4.3-4.6 ka BP (cal). Two other gullies were constrained within the two intervals 5.2-5.5 and 5.9-6.2 ka BP (cal), based on assumed correlation with extreme runoff events dated over the area. After a long break of erosion, two of the gullies had exhibited the second phase of activity between 3.0-3.7 ka BP (cal). As in the Bronze Age no settlements are known in the study area and surroundings; human reinforcement of erosion was minor if any. The four intervals of extraordinary linear erosion on valley sides coincided with extremely high runoff events in streams of various sizes, which left prominent geomorphic and sedimentological features: meander arcs, coarse-grained alluvium, buried floodplain soils, etc. Altogether, this is considered to indicate a highly irregular climatic pattern in the area in the interval of 3.0-6.2 ka BP (cal) with several phases containing a series of extreme downpours, which had no analogs throughout the Holocene.
\end{abstract}

Key words: erosion, gully, fan, extreme events, downpour, palaeoclimate, palaeohydrology, the Holocene

\section{INTRODUCTION}

The role of extreme hydrological events in sculpturing of a geomorphic landscape has been discussed repeatedly in the broader context of the landscape sensitivity and magnitude-frequency concepts (Wolman and Miller, 1960; Brunsden and Thornes, 1979; Bull, 1991; Crozier, 1999; Richards, 1999; Phillips, 2009; and others). Progress in improving temporal resolution of palaeoreconstructions have led to assessment of high geomorphological significance of short-term climatic variability (Viles and Goudie, 2003), in which the frequency of extreme runoff events has been demonstrated to be of primary importance for the evolution of fluvial systems (Starkel, 2007). On the other hand, traces of erosion and sedimentation anomalies may serve as important indicators of extreme hydroclimatic events which may not be detectable by other methods (Starkel, 1998, 2006). Development of gullies may represent one of such indicators of climatic extremity.

Recent gully formation and growth takes place in a wide range of environments and is clearly a response to anthropogenic disturbance of landscapes. Episodes of gully- 
ing have also been found to occur in ancient times. Known events of gully formation in central and western continental Europe were dated since the Late Neolithic (Schmidtchen and Bork, 2003) and the Bronze Age (Zygmunt, 2004; Schmitt et al., 2005; Vanwalleghem et al., 2006; Smolska, 2007). In most cases, gullying is thought to be associated with local landscape disturbances induced by activity of prehistoric man (Bork et al., 1998; Dotterweich, 2008). In steppe and forested-steppe regions of European Russia, more than $90 \%$ of existing gullies appeared during the period of extensive ploughing in the 17-19th centuries (Zorina et al., 1975). It was also proposed that in forested regions gullying is not a typical geomorphic process and may occur under anthropogenic enforcing only (Dedkov et al., 1977). However, several case studies were published describing gully formation in the Holocene under very limited or even non-existing man's impact, both in forested (Belyaev et al., 2005; Ere- menko et al., 2005; Panin et al., 2009) and in steppe (Panin et al., 1998; Panin et al., 2011) regions of the Russian Plain. In cases where man influence was insignificant, activation of erosion may be thought to have been linked to extreme runoff events indicative of prominent climatic conditions.

Here we present the case study of ancient gullying evidencing a number of extreme precipitation and runoff events or clusters of events, which could have not been detected from mean characteristics of palaeoclimate.

\section{NATURAL SETTLING AND HISTORY OF HUMAN IMPACT}

The study area is a 4 to $5 \mathrm{~km}$ territory located in the Borovsk District, one of 24 districts in the Kaluga Region some $100 \mathrm{~km} \mathrm{SW}$ from Moscow, $55^{\circ} 12^{\prime} \mathrm{N}, 36^{\circ} 22^{\prime} \mathrm{E}$ (Fig.1). It is the centre of the Russian Plain, the middle part of the Protva River catchment (the Oka

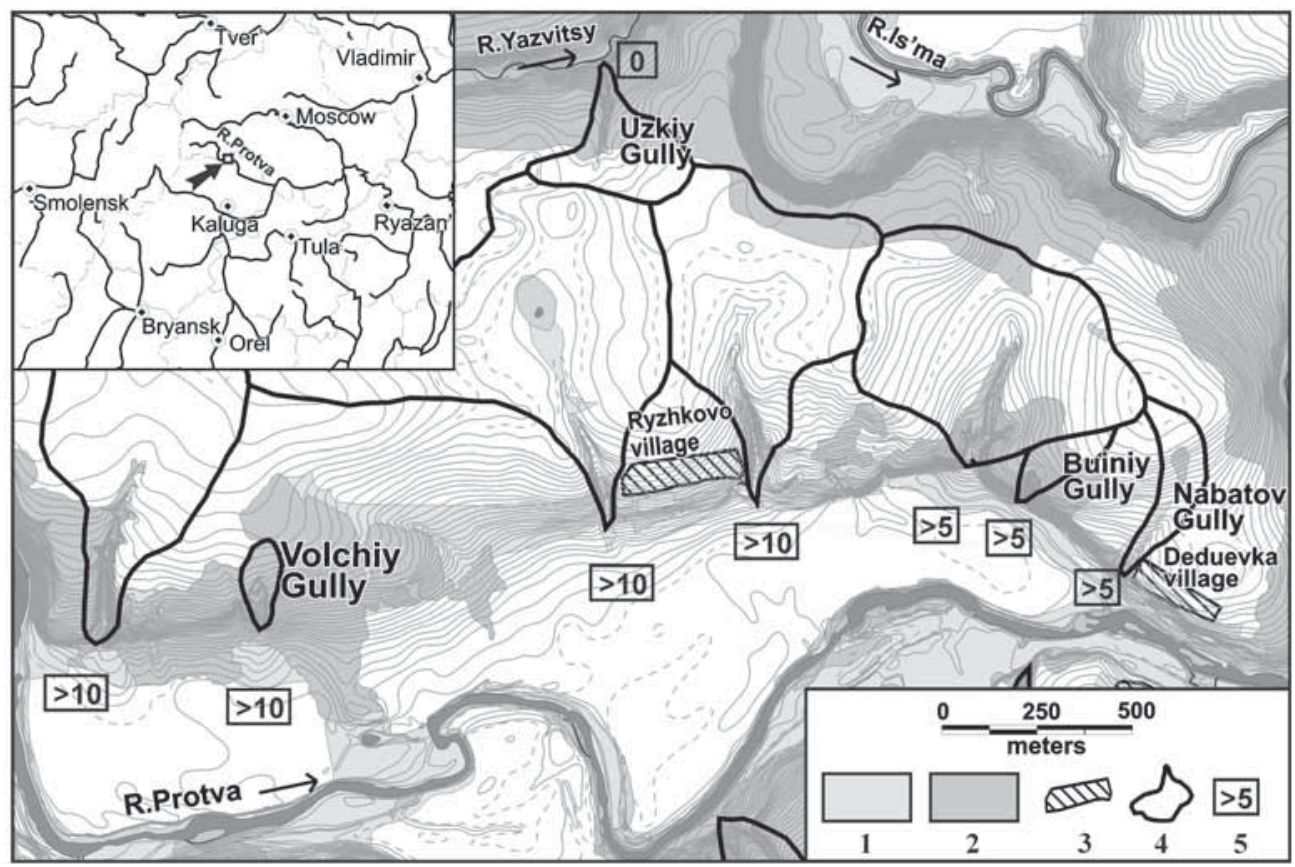

Figure 1. Location map.

1 - forests, 2 - meadows, 3 - settlements, 4 - gully catchments, 5 - estimation of time span (in radiocarbon years), during which valley sides and gully fans have not been undercut by lateral river erosion. 
River left tributary). Climate is temperate continental with mean temperatures $-10^{\circ} \mathrm{C}$ in January and $+18^{\circ} \mathrm{C}$ in July. Annual precipitation averages $600 \mathrm{~mm}$, of which about one third is snow. Mixed broadleaf/conifer forests dominate in natural vegetation.

Two different-aged geomorphic complexes dominate in terrain morphology of the area. Morainic topography formed in the end of the Moscow (Late Saalian, Warta) Glaciation (OIS-6) and smoothed by mass movements during the last $150 \mathrm{kyr}$ makes watershed landscapes with dominate slope angles $<2^{\circ}$ and $95 \%$ of the area being $<5^{\circ}$ steep. Post-glacial fluvial network is represented by the Protva River Valley (at the study site: catchment area $1,450 \mathrm{~km}^{2}$, mean annual discharge $9.9 \mathrm{~m}^{3} \mathrm{~s}^{-1}$ ) and a number of tributary valleys (Fig.1). Valley sides with dominating slope angles in the range $5-15^{\circ}$ and locally up to $35^{\circ}$ make the main scene for gully development.

Anthropogenic impact has being spread widely over the territory only since the Middle Ages, as it is illustrated by Table 1. The number of settlements founded per a century (the last column in Table 1) may be regarded roughly as an indicator of population density. In Prehistoric Times population density was negligible and, according to current knowledge, even zeroed in the Bronze Age. The oldest known settlements directly in the study area or in its close surroundings are dated to the 4-8th c. AD (Early Middle Ages) (see review in Panin et al. 2009). This is the most reliable estimation for the start of human influence over landscape in the study area, though most probably this influence was still negligible and no evidences of its occurrence have been found yet. The most severe forest clearance in the Middle Protva River catchment occurred in the mid-18th c. AD when forests covered only $7 \%$ of the area (today's value is $42 \%$ ) while arable land and settlements occupied $67 \%$ and $3 \%$, respectively (37\% and $8 \%$ today) (Antonov et al., 2005). Land cultivation and other kinds of anthropogenic impact, especially earth roads, promoted modern revival of erosion in the form of active rills and potholes in gully bottoms.

\section{OBJECTS AND METHODS}

Most of the gullies dissecting valley sides are of the Pleistocene origin and four gullies have been found to be of the Holocene age (Panin et al., 2009). Compared to the Pleistocene gullies, those formed in the Holocene are smaller in length (100-230 m versus 270-940 m) and catchment area (1.7-7.2 versus 9.7-63 hectares) (Fig 1). All Holocene gullies contain almost no sediments in their bottoms. History of their development was

Table 1. Number of known settlements in the Borovsk District throughout the Holocene (based on the catalog in Kashkin et al., 2006)

\begin{tabular}{lrrrr}
\hline & \multicolumn{2}{c}{ Chronology } & \multicolumn{2}{c}{ Number of settlements } \\
\cline { 2 - 5 } Epoch & $\begin{array}{l}\text { cal. years before } \\
\text { 2000 AD }\end{array}$ & century BC/AD & per epoch & per one century \\
\hline Mesolithic & $12,000-8,000$ & C-LXXX BC & 4 & 0.11 \\
Neolithic & $8,000-5,000$ & LXXX-XXX BC & 3 & 0.10 \\
Bronze Age & $5,000-2,800$ & XXX-VIII BC & 0 & 0 \\
Early Iron Age (EIA) & $2,800-1,800$ & VII BC-II AD & 7 & 0.70 \\
Early Middle Ages & $1,800-1,200$ & III-VIII AD & 13 & 2.2 \\
Slavic colonization & $1,200-1,000$ & IX-X AD & 5 & 2.5 \\
High Middle Ages & $1000-700$ & XI-XIII AD & 18 & 6.0 \\
Late Middle - Early Modern Ages & $700-300$ & XIV-XVII AD & 56 & 14
\end{tabular}


studied from sediment stratigraphy in gully fans. As all gullies open into the bottoms of river valleys, the completeness of sediment trapping in the fans is controlled by possible fan destruction by river lateral erosion. Reconstruction of the Protva River and its tributary valleys development in the Holocene (Panin et al., 1999; Panin and Karevskaya, 2000) promotes estimation of the time elapsed since the last undermining of the valley side at a given stretch, i.e. the potential destruction of each fan (Fig.1).

Pleistocene gully fans, which have been subject to lateral undercutting in the Holocene, constitute only a few percent of the corresponding gully volumes demonstrating obvious incompleteness of sedimentary records. The Holocene gullies at these stretches also demonstrate low relative volumes of their fans: the Uzkiy Gully $-<1 \%$, the Buiniy Gully - 4\%, the Nabatov Gully $-11 \%$. The Nabatov Gully fan ends at the middle of the valley slope, which promotes high sediment delivery efficiency. Therefore, small value of the fan relative volume comes rather from low trapping capacity of the fan than from lateral undercutting. Young age of this gully is supported by radiocarbon dates and land use history (see the Discussion section).

At valley side locations that have not been eroded during the whole of the Holocene (the last 10,000 radiocarbon years), the Pleistocene gully fans constitute from $5 \%$ to $28 \%$ of gully volumes. The only Holocene gully at such stretch (the Volchiy Gully) has the most representative fan with relative volume being $48 \%$ of the gully volume. This gully has been chosen for a special study of gully erosion in the Holocene.

The Volchiy Gully cuts the left side of the Protva River valley with total relief $20-22 \mathrm{~m}$ and slope of $7-10^{\circ}$. The whole gully system includes the main gully and three tributary gullies (Fig. 2). Along the whole length, all gullies have sharp edges and straight sides $20^{\circ}$ to $50^{\circ}$ steep. No headcuts are found both in the main gully and in its tributaries. In its upper course the main gully cuts a succession of sedimentary layers: cover loams,

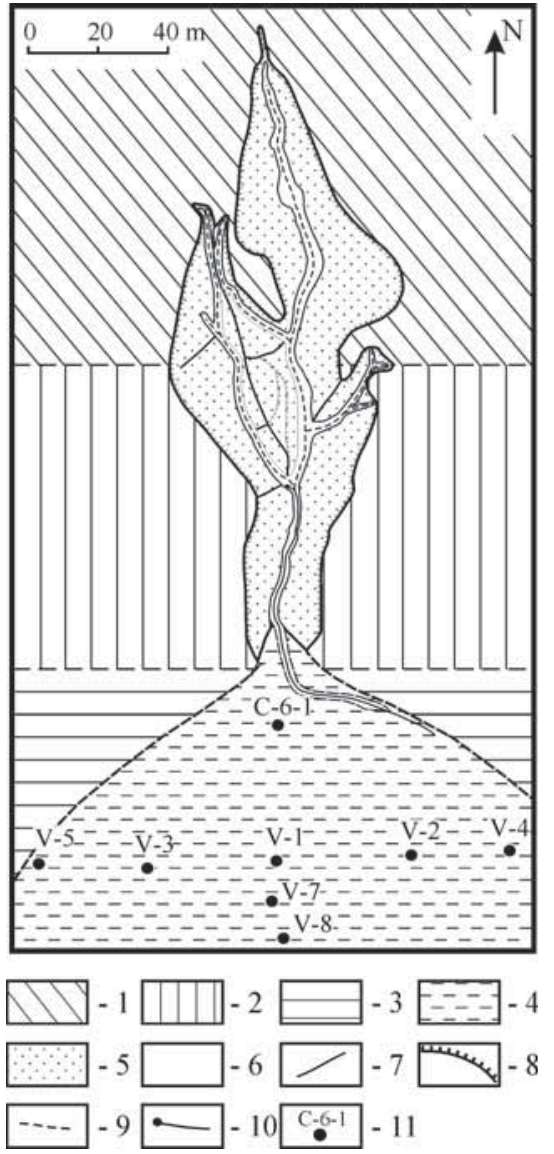

Figure 2. The Volchiy Gully system: geomorphic scheme.

Background geomorphic surfaces: 1 - Late Moscow (OIS-6) glacial outwash plain (sandur) ancestral to the river valley; 2 - valley side; 3 - piedmont slope: slope wash (deluvial) cover overlaying base of the valley side and back of low river terrace. Elements of the gully system: 4 - fan; 5 - sides; 6 - bottom; 7 - water-dividing lines; 8 - edges; 9 - thalwegs; 10 - spring and brook. Other: 11 - pits and cores.

glacio-fluvial sands and Moscow till, which is characterized by unusually high sand content at the site (Fig.3). Downstream, the gully dissects highly erodible 15 -m-thick glacio-lacustrine thin sands and silts. In the lower course the gully is cut into the roof of the Dnieper glaciation (OIS-8) till represented by very strong stony loams. The gully long profile is highly concave, disrupted 


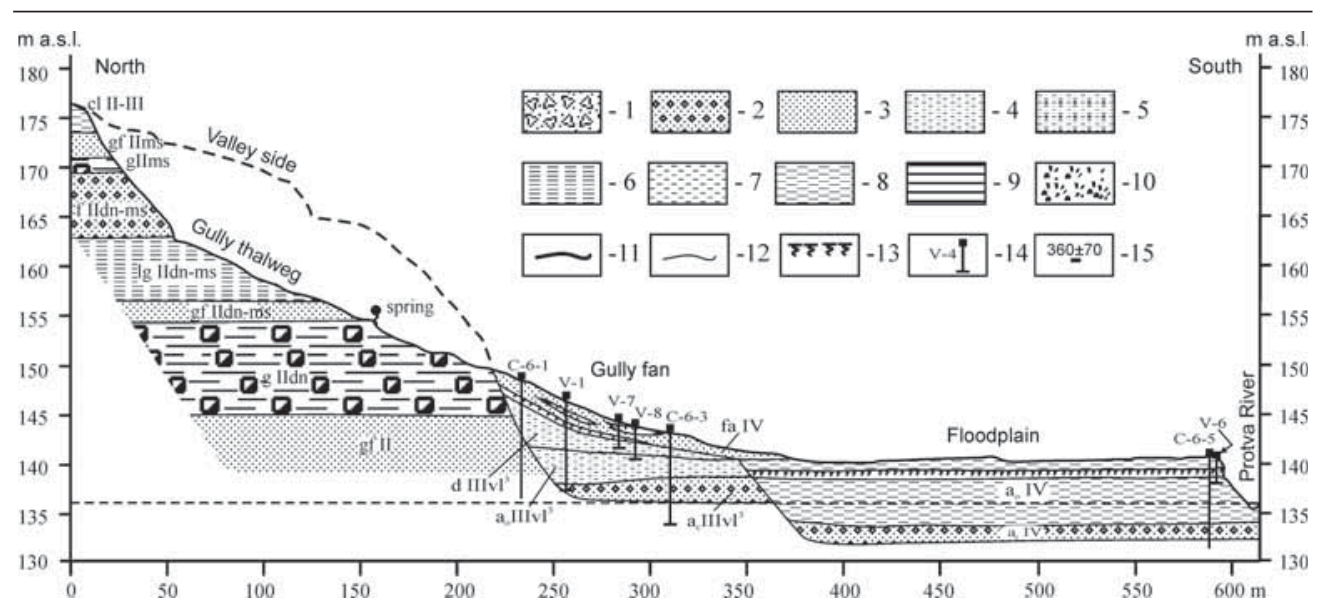

Figure 3. Geological section along the Volchiy Gully.

Legend: 1 - gravel and cobble with sand fill; 2 - coarse sand with admixture of gravel; 3 - medium to coarse sand; 4 - silty sand; 5 - silty sand with small gravel inclusions; 6 - silt and fine sand; 7 - silty loam; 8 - clayey loam; 9 - clay; 10 - concentrations of pebbles and cobbles; 11 - stratigraphic boundaries; 12 - lithological boundaries; 13 - modern and buried soils; 14 - cores; 15 - samples and ${ }^{14} \mathrm{C}$ dates.

Geologic indexes. Origin: $a_{c}$ - alluvium, active channel facies, $a_{o}$ - alluvium, overbank facies, cl-cover loams, $d$ - deluvium (slopewash deposits), fa - fan alluvium, g - glacial tills, gf - glacio-fluvial, $\mathrm{lg}$ - limnoglacial.

Age: II - Middle Pleistocene, dn - Dnieper stage (OIS-8), ms - Moscow stage (OIS-6); III - Late Pleistocene, $\mathrm{vl}^{3}$ - Late Valdai stage (OIS-2); IV - Holocene (OIS-1).

slightly by several lithologically controlled steps, 15-20 m long each (Fig.3). In spite of rather young appearance, the semi-equilibrium form of the profile and smooth outlines of the gully head evidence that the gully has already reached its growth limits. Actually, during the last 40 years when the gully has been being monitored continuously, no evidence of its activity has been detected.

The gully fan is $200 \mathrm{~m}$ wide at its broadest cross-section. It overlays the loam train which covers the base of valley side, protrudes over the floodplain and pinches out some $200 \mathrm{~m}$ away from the gully mouth. Fan sediments contain the record of the gully history. To study their stratigraphy, we excavated a number of pits and trenches along and across the fan (see Fig. 2 for location). Several pits were continued down by hand cores. In pit V-7 in the centre of the fan, sediment properties were studied by particle size, mineralogical and pollen methods. Most part of radiocarbon dating was processed at the Kyiv Radiocarbon Laboratory (Institute of Environmental Geochemistry, Ukrainian
National Academy of Sciences). Calibration of dates was made in the OxCal 3.1 program (Bronk Ramsey, 2005) using the IntCal'04 calibration curve (Reimer et al., 2004).

\section{RESULTS}

\section{STRATIGRAPHY OF THE FAN AND UNDERLYING SEDIMENTS}

Fan sediments are subdivided into two units that represent two phases of sedimentation (Fig. 4). The upper Unit 5 is composed of coarse sand with abundant inclusions of gravels and cobbles. In pit V-7, a solitary piece of the Dnieper till was found at the base of the unit. The lower Unit 4 is represented by sand with only rare inclusions of larger pieces in the centre of the fan (pit V-1). Grain size becomes thinner in lateral direction: across the fan (pits V-2, V-3, V-4) sand passes into silts and loams, and downwards (pits V-7, V-8) loam layers appear in the sand.

The fan overlays the Late Glacial deluvial (slope wash) loams that cover the base 


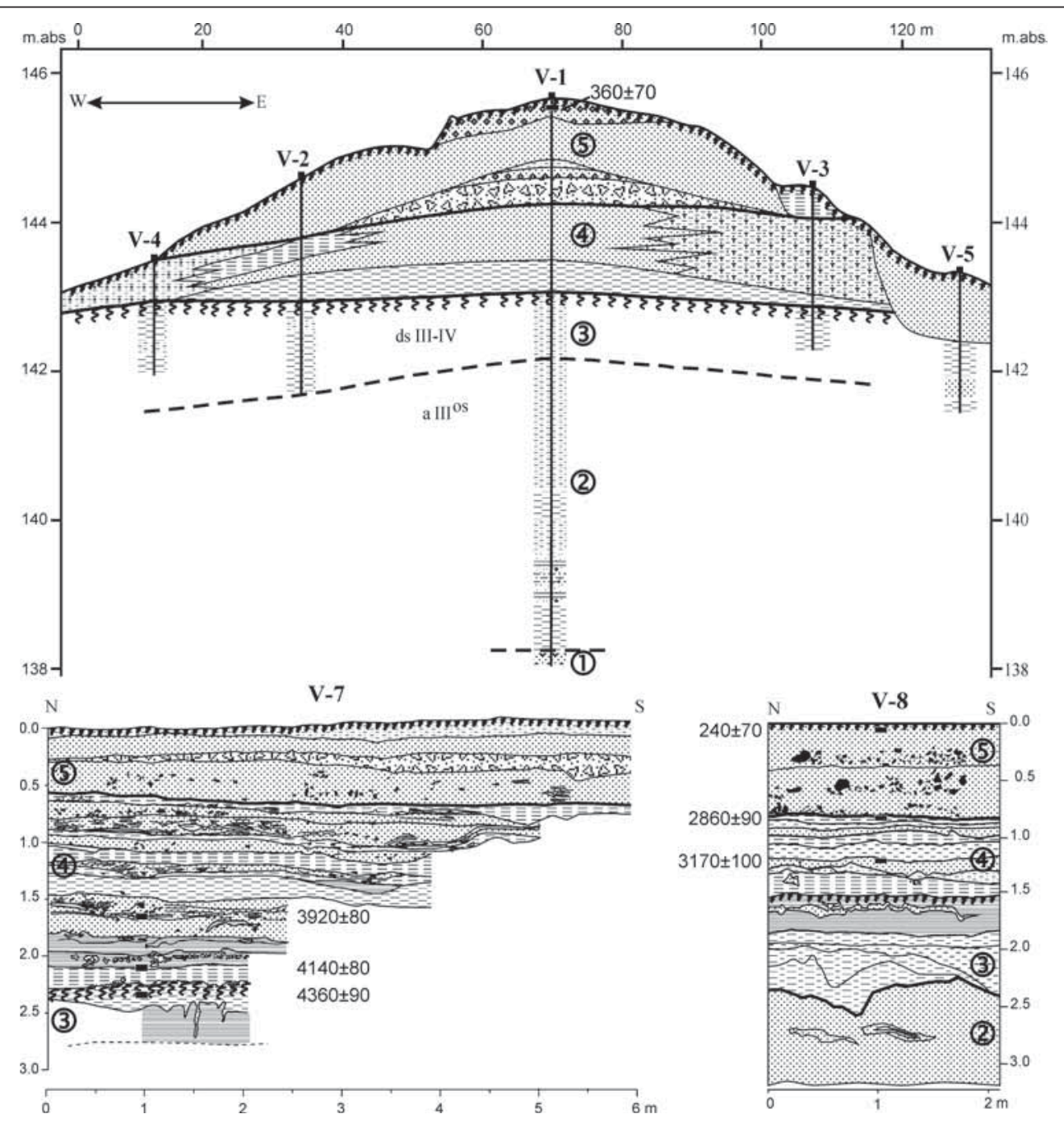

Figure 4. Geological section across the Volchiy Gully fan.

See Fig. 3 for explanation. Numbers in circles indicate stratigraphic units.

of the valley side (Unit 3). The roof of the loams is fixed by a well developed buried soil stratified into several horizons: dark-grey to black humus horizon (A1), transition horizon (A1A2), whitish-greyish disintegrated into thin plates and silt-rich podzolic (eluvial) horizon (A2), as well as brown illuvial horizon with clay covers (cutans) over prismatic soil units $\left(B_{t}\right)$. In all pits abundant big charcoals lay at the contact between fan sediments and deluvial loams. Initially, charcoals must have been laying on the surface of the soil, but now they are found in a $5-10-\mathrm{cm}$ interval both into the bottom of Unit 2 and into the roof of Unit 3. This is explained by viscous deformation of loam surface at the moment of burial and picking some pieces up by the mudflow coming from the growing gully. Appearance of the gully seems to be synchronous to production of charcoal that is radiocarbon-dated at: 4,140 \pm 80 (Ki-11553) - charcoal from the base of fan deposits, and 4,360 \pm 90 (Ki-11554) - charcoal from the A1 horizon of buried soil. 
Table 2. Radiocarbon chronology of the Volchiy Gully fan deposits

\begin{tabular}{|c|c|c|c|c|c|c|c|}
\hline No. & Date (index) & $\begin{array}{l}\text { Calendar } \\
\text { age, years BP } \\
(95,4 \%)\end{array}$ & Pit & $\begin{array}{l}\text { Depth, } \\
\mathrm{cm}\end{array}$ & $\begin{array}{l}\text { Dated } \\
\text { material }\end{array}$ & Lithology and stratigraphy & $\begin{array}{l}\text { Phase of } \\
\text { the gully } \\
\text { development }\end{array}$ \\
\hline 1 & $240 \pm 70(\mathrm{Ki}-11563)$ & $0-480$ & $\mathrm{~V}-8$ & $7-10$ & bulk & $\begin{array}{l}\text { Base of A- horizon of } \\
\text { modern soil }\end{array}$ & \\
\hline 2 & $360 \pm 70(\mathrm{Ki}-6469)$ & $290-520$ & $\mathrm{~V}-1$ & $7-12$ & bulk & $=$ No.1 & \\
\hline 3 & $2,860 \pm 90(\mathrm{Ki}-11562)$ & $2,770-3,250$ & $\mathrm{~V}-8$ & $81-84$ & bulk & Organic-rich loam layer & 2 \\
\hline 4 & $3,170 \pm 100(\mathrm{Ki}-11564)$ & $3,050-3,650$ & $\mathrm{~V}-8$ & $118-123$ & bulk & $\begin{array}{l}\text { Top of organic-rich loam } \\
\text { layer }\end{array}$ & 2 \\
\hline 5 & $3,920 \pm 80(\mathrm{Ki}-11552)$ & $4,090-4,570$ & $\mathrm{~V}-7$ & $165-170$ & bulk & Organic-rich loam layer & 1 \\
\hline 6 & $4,140 \pm 80(\mathrm{Ki}-11553)$ & $4,440-4,850$ & $\mathrm{~V}-7$ & $205-210$ & charcoal & Base of the gully fan & 1 \\
\hline 7 & $4,360 \pm 90(\mathrm{Ki}-11554)$ & $4,700-5,300$ & $\mathrm{~V}-7$ & $225-230$ & charcoal & $\begin{array}{l}\text { Top of the soil buried } \\
\text { under the fan }\end{array}$ & 1 \\
\hline
\end{tabular}

Dates from within the fan section (Table 2) give the idea about timing of fan accretion and therefore on the chronology of the gully development. It has to be taken into account that the two dates from the base of modern soil characterize the age of quickly renewing soil humus rather than the age of parent fan deposits, which must be much older.

Deluvial loams of Unit 3 change downwards by overbank alluvial facies of the ancient Protva River floodplain - sandy loams with thin lenses of sand (Unit 4). At 7.5-m depth they contact with Unit 5 - silty coarse sand with abundant inclusions of gravel interpreted as the active channel alluvium. Correlation of alluvial units to the adjacent reaches of the Protva River valley shows that they lay lower than alluvium of the Late Valdai (Late Vistulian) 8-10-m terrace but higher than the Holocene floodplain alluvium, implying river incision since the LGM till the Holocene (Panin, 2001). According to pollen data (see below), Unit 2 was probably accumulated in the Allerød.

\section{MINERALOGICAL COMPOSITION}

The spectrum of heavy minerals (density $\left.\mathrm{D}>2.9 \mathrm{~g} \mathrm{~cm}^{-3}\right)$ was studied in the fine sand fraction (0.1-0.25 mm) (Fig.5). Two parameters were calculated: coefficient of gravitation $\mathrm{C}_{\mathrm{G}}$ - ratio of minerals with density higher and lower than $3.4 \mathrm{~g} \mathrm{~cm}^{-3}$, and coefficient of resistance $C_{R}$ - ratio of minerals resistant and unstable to weathering, according to Ananyeva (1998). Both parameters exhibit rising upwards trends (Fig. 5). Of the two fan units, the upper Unit 5 is characterized by relatively high content of ilmenite and low content of garnet and hornblende. Mineralogical composition of underlying sediments is more uniform. Both deluvium (Unit 3) and overbank alluvium (Unit 2) exhibit higher content of hornblende, lower contents of ilmenite and rock fragment and almost no glauconite. Average values of $\mathrm{C}_{\mathrm{G}}$ and $\mathrm{C}_{\mathrm{R}}$ in deluvium are lower than in the fan and in river alluvium - lower than in deluvium.

Reference to mineralogical composition of Quaternary strata cut by the gully described by Sudakova et al. (1977) reveals that mineralogical characteristics of the fan und underlying sediments are indicative both of sediment source and dynamics of sedimentation. Increase of ilmenite and decrease of horhblende in the fan relative to deluvium and alluvium corresponds well to the upward rise of $\mathrm{C}_{\mathrm{G}}$ and sediment grain size, therefore, it reflects residual accumulation of heavier and depletion of lighter minerals due to rise of transporting flow velocities. The same conclusion is valid for the upper and lower units of fan deposits: the younger phase of fan accretion was more dynamic than the initial phase. Higher $C_{R}$ values in 





the fan and deluvium than in alluvium reflect the inheritance of fan deposits from local Quaternary strata that had undergone long in-situ weathering. Contribution of different sediment sources to the fan (concentrated influence of few local sources) and alluvium (mixture over river catchment) is illustrated by abundance of glauconite in the fan and its almost absence in alluvium: glauconite is most characteristic for the Dnieper till cut by the gully in the lower course and is relatively rare in other Quaternary deposits of the area (Sudakova et al., 1977). Upward rise of glauconite in the fan indicates more important role of this source in the youngest sedimentation phase (Unit 5).

\section{POLLEN DATA}

The pollen diagram was subdivided into three pollen zones (PZ), which correspond well to the lithological units (Fig.6).

PZ1 corresponds to alluvial sediments in the depth range 4.3-3.4 $\mathrm{m}$ (the upper part of Unit 3 in the interval 3.4-2.9 $\mathrm{m}$ was not sampled). Pollen spectra are similar in all samples pointing to their good averaging over the territory characteristic for alluvium. Dominant is arboreal pollen in which spruce (Picea) pollen prevail. Second ranked in the arboreal-shrub group is birch (Betula), in whose pollen up to $12-15 \%$ of grains belong to shrub birches (Betula sect. Fruticosae). Perceptible are also broadleaf species, such as: oak (Quercus, 0-5\%), elm (Ulmus, 1-5\%), lime (Tilia, 0-5\%), and hazel (Corylus, 0-3\%). Among herbaceous plants prevailing are sedges (Cyperaceae), grasses (Gramineae), sages (Artemisia), and goosefoot (Chenopodiaceae). In the Goosefoots Family, several steppe specimens were found (Kochia prostrata, Eurotia ceratoides, etc.). Among sages some xeromorphic species are present. Ecological ranges of individual species evidence high diversity of ecosystems and edaphic conditions.

PZ1 correlates well to the Allerød-dated lacustrine and bog sections at the southern edge of the Uglich Upland (about $250 \mathrm{~km}$ to the north), where some combination of ecologically diverse plants is also typical
(Khotinskiy, 1977). PZ1 resembles also Allerød palynological spectra from Belorus where Yelovicheva et al. (1988) found the relative rise of arboreal pollen with the dominant role of coniferous species, such as pine (Pinus) $-50-80 \%$, fir (Picea) - 10-40\%, and presence of alder (Alnus) - up to $3 \%$ and broadleaf trees $-2-5 \%$. The pre-Holocene rise of Picea is known widely over the centre of the Russian Plain; it is called "Picea lower maximum" and is considered as one of the indicators of the Allerød (Khotinskiy, 1977).

PZ2 corresponds to lithological Unit 3 (deluvium). The presence of taxa is only indicated in the pollen diagram (Fig. 6), as pollen output from the samples was too low to calculate statistical values. This is probably due to rather fast sedimentation rates of deluvium.

PZ3 corresponds to fan deposits. They exhibit several specific features:

(1) In the total spectra composition prevailing are herbs (35-55\%); trees and shrubs are found in smaller quantities close to those of spores (10-35\%).

(2) In arboreal pollen dominant (up to $55 \%$ ) is birch - Betula sect. albae (Betula pubescens et Betula verrucosae).

(3) High occurrence of shrub birch pollen (up to 17\%), which is considered as re-deposited due to two reasons: (a) arctic species of Betula are ecologically non-compatible with rather heat-loving flora of temperate mixed forests and grass meadows; (b) pollen grains of shrub birches and pre-Quaternary flora (see below) are found together in the depth range $0.9-1.5 \mathrm{~m}$, what is obviously explained by re-deposition from eroded tills that are composed of a mixture of different stratigraphic units.

(4) Among herbs and spores abundant are: Gramineae, Cyperaceae, Liliaceae, Cruciferae, Asteraceae, Chicoriaceae, Rosaceae, Taracsatum, Compositae, Iridaceae, Chenopodiaceae, Bryales, Sphagnum, Polypodiaceae, Ophyoglossaceae, Lycopodium sect. Clavatae, Eguisetum, liverworts, etc. 

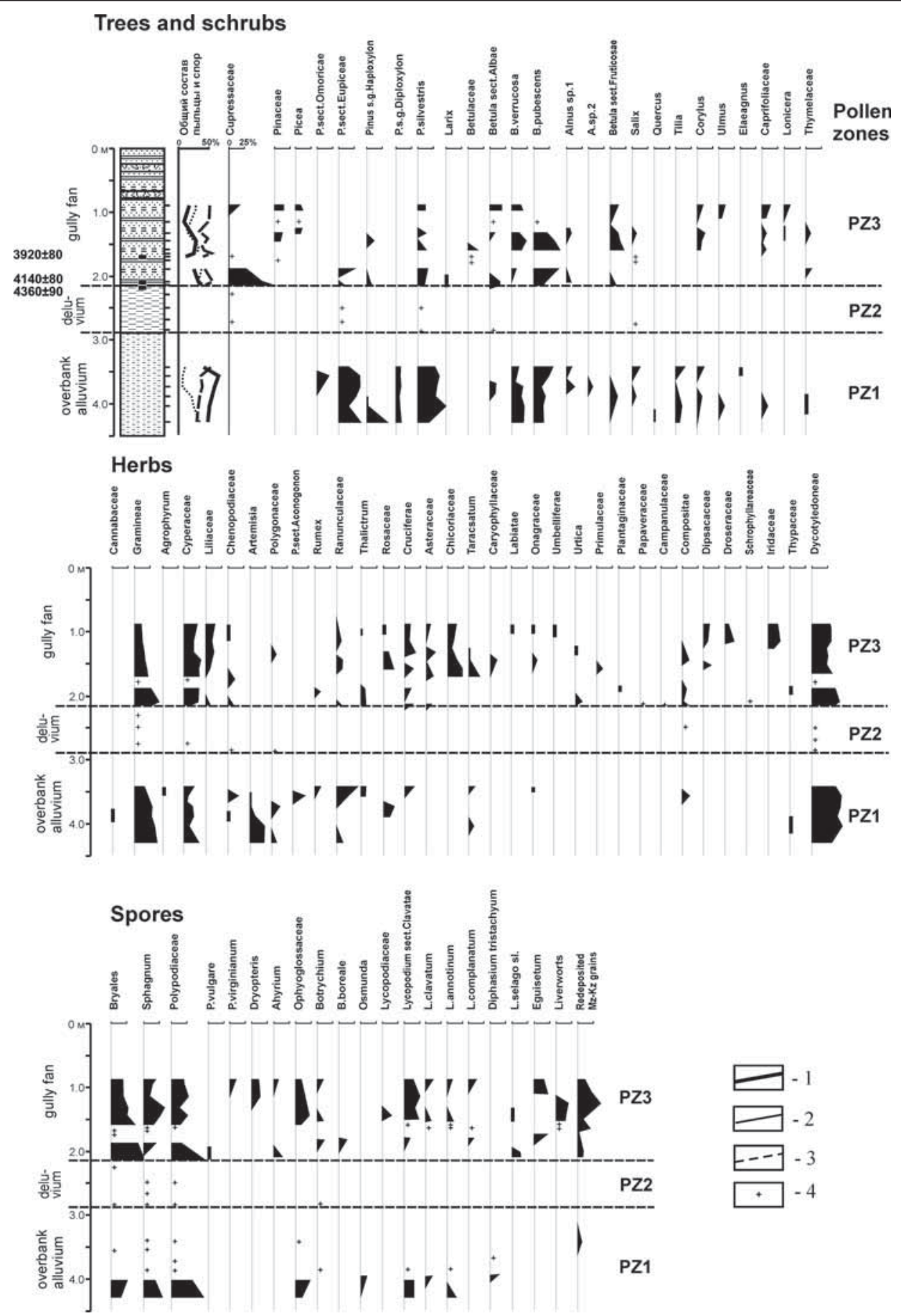

Figure 6. Pollen diagram of the Volchiy Gully fan and underlying deposits

Total percentage: 1 - trees and shrubs, 2 - herbs, 3 -spores, 4 -indication of a taxon presence if number of pollen grains in a sample was insufficient for statistical treatment. 
(5) High occurrence of ancient microfossils re-deposited from Jurassic/Palaeogene/ Neogene rocks with the peak at the middle part of fan deposits (35\% at $1.25 \mathrm{~m}$ ).

(6) High amplitude of percentage change between neighbouring samples, what results in ragged outlines of pollen curves.

(7) Envelopes of most grains are deformed (flattened, crushed, etc.), many grains have scuffed, thinned exine.

All the above data evidence a mixed nature of fossil pollen spectra resulted from their formation in the course of erosion of moraine and inter-moraine deposits. Pollen spectra are characterized by low degree of spatial averaging and reflect mostly local vegetation - grass cover with dominant sedges and true grasses and admixture of liverworts, horsetail, adder's tongue family, various species of clubmosses, some irises, lilies, asters, preferring mostly wet localities, often with disrupted soil cover. The share of forested areas cannot be considered surely, but it is clear that they existed in the very vicinity and had mixed deciduous/coniferous composition. Dominant tree species were various birch species. Less abundant were dark coniferous (spruce), light coniferous (pine tree, larch) and broadleaf taxa (elm, hazel). According to radiocarbon data (Table 2), such ecosystems existed here in the second half of the Subboreal $(2.8-4.0 \mathrm{ka}$ (uncal) BP).

\section{RECONSTRUCTION OF THE VOLCHIY GULLY DEVELOPMENT}

Gully appearance had been pre-conditioned by the Protva River lateral erosion against the left side of the valley and formation of the steep slope here. It occurred at the beginning of the Late Glacial, not later than 12 ka BP (uncal), as in the Allerød (11-12 ka BP (uncal)) overbank alluvium at the site of the future gully fan was being accumulated, what proves that the river had already shifted to the opposite side of valley bottom by that time. Once the floodplain was formed, the deluvium washed from the adjacent slope covered its edge making the cover up to 3-4 meters thick (Fig.3).
Given that the valley side is composed principally of sands and silts, the loamy composition of deluvium may be explained only by its origin from the Dnieper till, which is exposed at the base of the slope (Fig. 3). Groundwater released over the top of the waterproof moraine layer served as the source of water for slope wash. Rainfall and snowmelt waters did not participate in this process, otherwise the diluvium would contain high admixture of sand and even gravel both from the layers upslope and from the moraine itself. Slope wash is most probably to have proceeded at the end of the Late Glacial and declined at the beginning of the Holocene due to increase in vegetation density. Early decline of deluvium accumulation is proved by formation of well-developed soil on its surface, which later was buried under the gully fan. Such properties of the soil profile as thick subsoil illuviation (B-horizon) required several thousand years to pass between the stabilization of the surface (stop of deluvium accretion) and the soil burial.

According to radiocarbon dates, there is $>95 \%$ probability that the gully appeared between 4,440 and 5,300 cal. years BP (nos. 6, 7 in Table 2). Taking into consideration the whole spectrum of palaeohydrological events in the study site, which we are aware of, the most probable time span for the gully formation may be limited to 4,300-4,600 cal years BP (see the Discussion section below). The gully formation was promoted by the coincidence of two extreme events: forest fire destroying vegetation cover on the slope (note large charcoals under the fan) and a heavy downpour, which followed not necessarily immediately, but probably during few coming years.

Gully incision started in the middle of the slope composed of most erodible sand and silt deposits. Initially, two competing rills formed and developed into small gullies, one of which eventually intercepted the other (Fig. 2). Two-member stratigraphic composition of the fan (Units 4 and 5) provides a two-stage gully development model. The first stage of the gully system development was relatively quiet with graduate ero- 
sion and lasted about 1-2 thousand years. About half of the fan thickness and some 4/5 of its volume, which means also the volume of the gully, had formed during that time.

The second phase consisted of several erosion events of extreme intensity. They induced debris flows that ran on the fan and left the coarse-grained upper part of the fan (lithological Unit 5). They must have caused deepening of the gully long-profile. The grain-size and mineralogical compositions of Unit 5 evidence that the gully incised both into the Dnieper till in the lower course and into the Moscow till in the upper course. Therefore, the gully should have lengthened due to both headward and downward erosion and deepened over its whole length. The last of the debris flows occurred at the same time as the last erosion event in the gully. With $95 \%$ probability, it occurred between 3,250-2,770 cal years BP (Table 2, Fig. 4). Given the dates on gully initiation, the total period of its active development lasted between 1,150 and 2,530 years (at 95\% probability).

The long lasting stabilization of the gully is confirmed by the dates on humus from the base of modern soils on the fan surface. They evidence absence of sedimentation during the last at least 400-500 years. Given the constant rotation of soil humus promoted here by sandy soil structure, it may be considered that the dates underestimate the real duration of the fan stabilization. Therefore, it looks reasonable to rely on fan stratigraphy and consider the absence of fan accretion and corresponding gully erosion for the last ca. 3 thousand years.

\section{AGE AND DRIVING FORCES OF OTHER HOLOCENE GULLY FORMATION}

The Volchiy Gully is one of the four Holocene gullies in the Satino area (Eremenko et al., 2005; Panin et al., 2009). Of them, only the Nabatov Gully has probably formed due to anthropogenic impact: it is located at the edge of the Deduevka village and is unusually straight (Fig.1), maybe because it had cut along an earth road or land-mark trench. The Deduevka village is known since the 14-16th c. AD. The gully fan was dated by charcoal at the base of fan sediments at $620 \pm 65$ (Ki-6164), which calibrates to AD $1,270-1,430(95 \%)$ and fits well to the age of the adjacent village.

The two other Holocene gullies are much older. Radiocarbon dates $1,040 \pm 70$ (Ki-10843) and 3,420 105 (Ki-6160), respectively, were obtained at the base of their fans (Panin et al., 2009). In both cases fan volumes are much smaller than the gully volumes, i.e. the modern fans are younger than the gullies and ancient fans, which correspond to initial phases of gully formation, had already been eroded. Therefore, establishing of gully age is possible from indirect data only.

The Buiniy Gully fan overlies a 20-m-wide bench cut by the ancient channel of the Protva River, which had been abandoned shortly before 4,970 100 uncal yrs BP (Ki-6175) (Panin and Karevskaya, 2000). As in the case of the Volchiy Gully, unstable sands lying between two tills in the middle of the slope facilitated gully initiation here. Small volume of the fan evidences that initially gully sediments were being delivered directly to the river and were washed out. Therefore, the ancient channel must have been active still during the initial phases of gully development, and gully initiation must have occurred shortly before 5,000 radiocarbon years BP. Fan accretion became possible only after the river channel had been abandoned. Given that the base of the fan is dated at some 3,400 radiocarbon years $\mathrm{BP}$, there must have occurred a $1.5 \mathrm{ka}$ break in gully erosion after its initial active phase.

The Uzkiy Gully opens into the Yazvitsy rivulet (Fig.1). In the second half of the Holocene, there were two periods of high floods and active erosion in the Yazvitsy valley dated at 4,200-4,700 and 600-1,100 radiocarbon years BP (Panin et al., 1999). During the latter period, the Uzkiy gully was also active exhibiting bottom incision by $1-2 \mathrm{~m}$ and formation of the modern fan (Eremenko et al. 2005). Consequently, the gully is much 
older and appeared probably during the first period of activity between $4.2-4.7 \mathrm{ka}$ uncal BP. Its initial fan must have been eroded by the then powerful Yazvitsy stream.

The Uzkiy Gully is the only one of the Holocene gullies to cut entirely into hard till deposits. It became possible due to relatively large catchment area -7.2 ha. On sandy slopes gully initiation has required much less catchment areas: the Volchiy Gully -1.7 ha, the Buiniy Gully -2.3 ha. Unlike the Volchiy Gully, the Uzkiy and Buiniy gullies have not reached an equilibrium profile and are still active nowadays (Bolysov and Tarzaeva, 1996).

According to the above data, three of the four Holocene gullies in the Satino area had cut into steep valley sides between $4-5.5 \mathrm{ka}$ uncal, i.e. at the end of the Atlantic - start of the Subboreal periods. Occurrence of such rare events within a relatively short time span could not have been casual.

\section{DISCUSSION}

\section{CAUSES AND CONDITIONS OF GULLY DEVELOPMENT IN THE MID-HOLOCENE}

Development of three new gullies was unique in the Satino area at the Holocene scale, except for the youngest and smallest Nabatov Gully. In the case of the latter, indications are that it was local anthropogenic impact to be accounted for its appearance. On the other hand, no evidence of human impact over the area existed in the Mid-Holocene when the other three gullies developed: it was the Bronze Age when the Holocene-lowest, probably zero, population existed in the region (see Table 1). Therefore, some extraordinary natural conditions must have been responsible for this anomalous display of erosion.

In the Satino area, distinct geomorphic and sedimentological features are known, which indicate extremely high floods in the Protva River and its tributaries in several epochs within the Mid-Holocene (Panin et al., 1999, 2009; Panin, 2001, 2008; Belyaev et al., 2003; Vlasov, 2005). Radiocarbon dates of these traces with indication of their relation to respective flood events (pre-dating, synchronism, post-dating) are summarized in Table 3. Dates from Table 3 with several supplements from Table 2 are grouped in Fig. 7, according to their relevance to respective hydroclimatic events, and probable time spans containing these events or series of events are shown. Four epochs of extreme hydroclimatic events are detected.

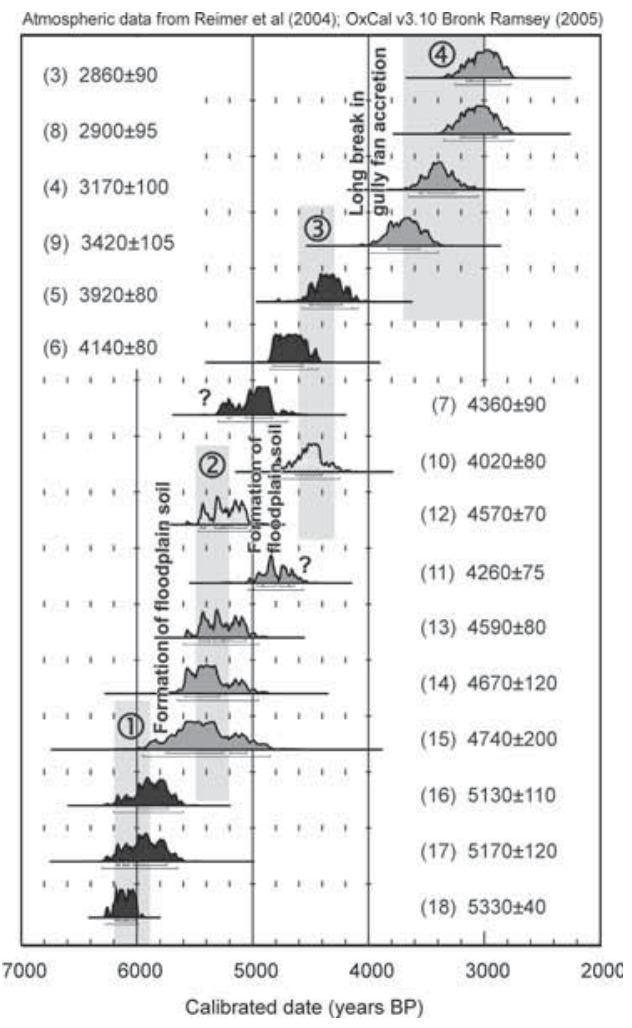

Figure 7. Periods of high fluvial activity (gully erosion, high-magnitude floods in rivers) deduced from radiocarbon dating of prominent palaeohydrological events.

Periods containing traces of high fluvial activity are shown as light grey strips and circled numbers. Colour of probability distribution graphs display relation of dates to different periods of high runoff. Dotted are dates indicating low runoff periods. Date numbers (in brackets) correspond to Tables 2 and 3. 
Table 3. Absolute chronology of geomorphic and sedimentological features indicating prominent Mid-Holocene flood events at the Satino site. Date numbers follow Table 2.

\begin{tabular}{|c|c|c|c|c|c|c|}
\hline No. & Date (index) & $\begin{array}{l}\text { Calendar } \\
\text { age, years BP } \\
(95,4 \%)\end{array}$ & Material, stratigraphy & Event (epoch) & $\begin{array}{l}\text { Date } \\
\text { relation to } \\
\text { the event } \\
(\text { epoch)* }\end{array}$ & Source \\
\hline 8 & $\begin{array}{l}2,900 \pm 95 \\
(\mathrm{Ki}-6159)\end{array}$ & $2,800-3,330$ & $\begin{array}{l}\text { Charcoal from within } \\
\text { the fan }\end{array}$ & $\begin{array}{l}\text { The Buiniy Gully, 2nd phase } \\
\text { of activity (finish) }\end{array}$ & M & $\begin{array}{l}\text { Panin, 2008; } \\
\text { Panin et al., 2009; }\end{array}$ \\
\hline 9 & $\begin{array}{l}3,420 \pm 105 \\
(\mathrm{Ki}-6160)\end{array}$ & $3,410-3,960$ & $\begin{array}{l}\text { Charcoal from the } \\
\text { base of the fan }\end{array}$ & $\begin{array}{l}\text { The Buiniy Gully: second } \\
\text { phase of activity (start) }\end{array}$ & $\mathrm{S}+$ & $\begin{array}{l}\text { Panin, 2008; } \\
\text { Panin et al., 2009; }\end{array}$ \\
\hline 10 & $\begin{array}{l}4,020 \pm 80 \\
(\mathrm{Ki}-6466)\end{array}$ & $4,260-4,820$ & $\begin{array}{l}\text { Humus from the top } \\
\text { of buried alluvial soil }\end{array}$ & $\begin{array}{l}\text { Increase in frequency and } \\
\text { depth of the Protva River }\end{array}$ & S- & Panin, 2001; \\
\hline 11 & $\begin{array}{l}4,260 \pm 75 \\
(\mathrm{Ki}-6441)\end{array}$ & $4,550-5,035$ & $\begin{array}{l}\text { Charcoal from the } \\
\text { alluvial bar sands }\end{array}$ & $\begin{array}{l}\text { Formation of sand terrace } \\
\text { with large meander arcs in } \\
\text { the Yazvitsy valley }\end{array}$ & M & Panin et al., 1999; \\
\hline 12 & $\begin{array}{l}4,570 \pm 70 \\
(\mathrm{Ki}-6467)\end{array}$ & $4,980-5,470$ & $\begin{array}{l}\text { Humus from the base } \\
\text { of buried alluvial soil }\end{array}$ & $\begin{array}{l}\text { Decline of frequency and } \\
\text { depth of the Protva River }\end{array}$ & $\mathrm{S}+$ & Panin, 2001; \\
\hline 13 & $\begin{array}{l}4,590 \pm 80 \\
(\mathrm{Ki}-6442)\end{array}$ & $4,950-5,600$ & $=$ No.11 & $=$ No.11 & M & Panin et al., 1999; \\
\hline 14 & $\begin{array}{l}4,670 \pm 120 \\
(\mathrm{Ki}-8419)\end{array}$ & $4,950-5,650$ & $\begin{array}{l}\text { Charcoal from the } \\
\text { base of overbank } \\
\text { alluvial facies }\end{array}$ & $\begin{array}{l}\text { Burial of a forest-type soil } \\
\text { on the Cholokhovskiy rivulet } \\
\text { floodplain }\end{array}$ & $\mathrm{S}+$ & $\begin{array}{l}\text { Belyaev et al., } \\
\text { 2003; }\end{array}$ \\
\hline 15 & $\begin{array}{l}4,735 \pm 200 \\
(\mathrm{MGU}-1474)\end{array}$ & $4,850-5,950$ & $=$ No.11 & $=$ No.11 & M & Panin et al., 1999; \\
\hline 16 & $\begin{array}{l}5,125 \pm 110 \\
(\mathrm{Ki}-8418)\end{array}$ & $5,650-6,200$ & $\begin{array}{l}\text { Charcoal from the } \\
\text { top of coarse grained } \\
\text { active channel } \\
\text { alluvium }\end{array}$ & $\begin{array}{l}\text { Transportation of } \\
\text { cobble-sized alluvium } \\
\text { by strong floods in the } \\
\text { Cholokhovskiy rivulet }\end{array}$ & $\mathrm{E}+$ & $\begin{array}{l}\text { Belyaev et al., } \\
\text { 2003; }\end{array}$ \\
\hline 17 & $\begin{array}{l}5,170 \pm 120 \\
(\mathrm{Ki}-8414)\end{array}$ & $5,660-6,260$ & $=$ No.16 & $=$ No.16 & $\mathrm{E}+$ & $\begin{array}{l}\text { Belyaev et al., } \\
\text { 2003; }\end{array}$ \\
\hline 18 & $\begin{array}{l}5,330 \pm 40 \\
(\mathrm{GIN}-12374)\end{array}$ & $\begin{array}{l}5,990- \\
6,270\end{array}$ & $\begin{array}{l}\text { Wood from the base } \\
\text { of infill at the trace } \\
\text { of channel avulsion }\end{array}$ & $\begin{array}{l}\text { Large avulsion of the } \\
\text { Protva River }\end{array}$ & $\mathrm{E}+$ & Vlasov, 2005; \\
\hline
\end{tabular}

* Date interpretation: $\mathrm{S}$ - start (S- lower, S+ upper estimation), $\mathrm{M}$ - middle, $\mathrm{E}$ - end of an event (epoch) (E- lower, E+ upper estimation).

Epochs 1 (5,900-6,200 cal years BP) and $2(5,200-5,500$ cal years BP) are the most probable alternative estimations for the Uzkiy and Buiniy gully formation. They are separated by a period of low flood activity marked by formation of a forest-type soil on the floodplain of the Cholokhovskiy rivulet. Epoch 2 was followed by a period of the Protva River low floods when floodplain sedimentation rates declined and floodplain soil was forming. Epoch 3 (4,300-4,600 cal years BP) includes initiation and the first erosion phase of the Volchiy Gully system.
The subsequent erosion break and renewal of gully activity and fan accretion in Epoch 4 $(3,000-3,700$ cal years BP) are found both in the Volchiy and Buiniy gullies.

Extreme hydroclimatic events in the Satino area occurred on the background of high-amplitude climatic change at the Atlantic - Subboreal transition: the Late Atlantic temperature optimum was followed by the coolest span in the second half of the Holocene (Fig. 8A). The Late Atlantic was characterized by rather dry climate: river runoff in the Oka River catchment was $20 \%$ 

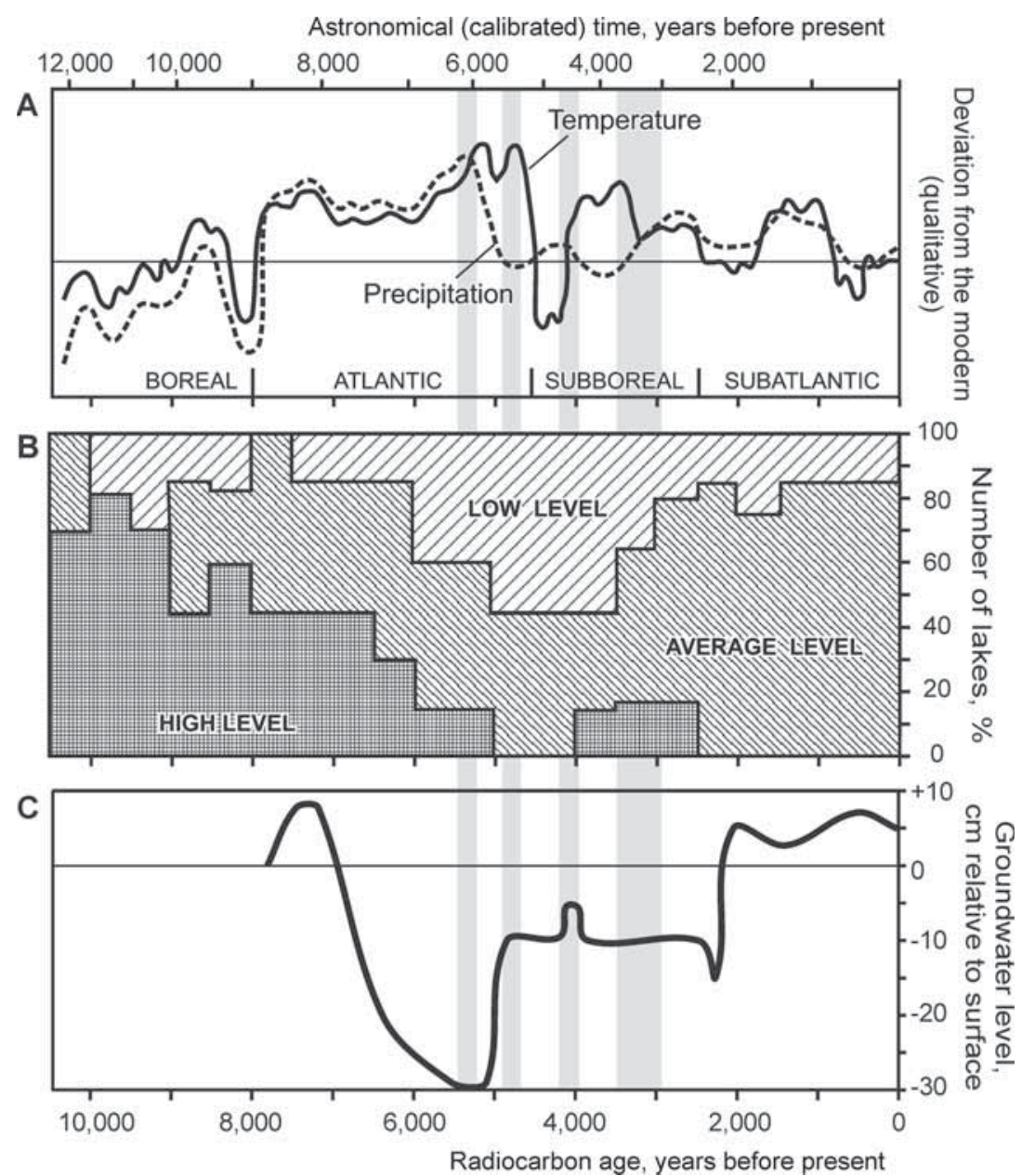

Figure 8. Holocene hydroclimatic changes in the centre of the Russian Plain.

A - temperature and precipitation (after Khotinskiy 1989); B - groundwater levels in raised bogs, the Meshchera Lowland (after Dyakonov and Abramova 1998); C - lake levels in the upper Volga River catchment (after Tarasov et al., 1997). Grey strips are Mid-Holocene phases of high fluvial activity of gullying in the Satino area shown in Fig.7.

less than the present value (Velichko et al., 1988), lake status in the Upper Volga River catchment was at its Holocene minimum (Fig. 8B). A sharp temperature drop at the Atlantic - Subboreal transition was not accompanied by equivalent change of general humidity: rise of groundwater table was detected in raised bogs (Fig. 8C), but rise of precipitation was small (Fig. 8A) and lake levels still stayed low (Fig. 8B). It may be inferred that, in terms of mean climatic conditions, episodes of gullying (Epochs 1-3) relate to unordinary time spans, one far above and the other far below the Holocene average temperature level, with the Holocene highest amplitude of change between them. Probably, these extremities of mean climate produced favourable background for extreme weather occurrences.

The extraordinary character of the Mid-Holocene erosion events and their hydroclimatic drivers is supported by the case of the Volchiy Gully, which developed with a some 10-ka delay after the favourable geo- 
morphic conditions had been established (the valley side lateral undercutting in the Late Glacial). Therefore, no hydroclimatic extremities may be considered to occur in the first half of the Holocene, which were strong enough to induce gully erosion. In the last centuries, anthropogenic forest clearance must have produced favourable conditions for gullying, but no massive appearance of new gullies has occurred. The only exception is the Nabatov Gully, which was promoted rather by road erosion than by land cultivation (see above). This is the evidence that precipitation extremities in the end of the Holocene did not reach their Mid-Holocene levels.

Nevertheless, forest clearance was the necessary condition for gully development in all times. In the Mid-Holocene, charcoals occurring everywhere inside and at the base of gully fans point to forest fires as the predecessor for gully erosion. It must be noted that remarkable differences exist in spatial patterns of vegetation clearance by humans and by fire. Cultivation is spread over gentle areas only with steep slopes left undisturbed. Fires destroyed forest everywhere with no respect to geomorphic position, and bared steep valley sides exhibited most susceptible locations for erosion. Combined with the Mid-Holocene rise of magnitude and frequency of extreme weather and respective runoff events, this provided conditions for unusually intensive erosion on slopes.

The catchment size is a factor controlling geomorphic response to different types of hydrometeorological events. In the lowland part of the Vistula River basin, notable geomorphic response of small catchments $\left(<5 \mathrm{~km}^{2}\right)$ is related rather with flash floods generated by heavy local downpours than with continuous rains at frontal zones or long rainy seasons lasting several weeks, with the minor role played by spring snowmelt (Starkel 2007). Given their small catchment area, development of Mid-Holocene gullies in the Satino site must have also been driven by heavy rainstorm events rather than by snowmelt, which was reported by Bolysov and Tarzaeva (1996) to dominate in modern gully erosion. During the Holocene thermal optimum, heavy downpours could have been caused by convective air movements characteristic for hot dry summer weather. In the cool Early Subboreal they could have been produced by atmospheric fronts.

\section{CORRELATION WITH ANCIENT GULLYING IN CENTRAL EUROPE}

According to Starkel (2000), in Central Europe the highest concentration of extreme events marked cold climatic fluctuations. Starkel (2005) found out that the most distinct geomorphic changes of slopes and valley floors occur under the coincidence of wetter climate and high anthropogenic pressure. He recognized such phases in Central Europe during the middle Neolithic period, the early phase of the Roman period, the 10th-11th century and the Little Ice Age. Dotterweich (2008) reviewed the Holocene history of erosion in Central Europe and concluded that peaks of sheet erosion and gullying corresponded to phases of rapid climate change characterized by extreme hydrometeorological events. This conclusion fits well to what has been concluded in the above for the Satino site, but ages of gully systems seem to be quite different.

Wide occurrence of pre-historic buried gullies and evidences of fan aggradation (Schmidtchen and Bork, 2003; Zygmunt, 2004; Schmitt et al., 2005, 2006; Smolska, 2007) provide examples of gully development in Central Europe in ancient times. Nevertheless, most of today's gully systems in Central Europe are believed to have been formed during the two phases of extraordinary precipitation occurring in the first half of the 14th and in the mid-18th to the early 19 th century, and were pre-conditioned by land cultivation (Bork et al., 1998; Dotterweich, 2008). In the Satino site, most gullies are pre-Holocene (Panin et al., 2009) or Mid-Holocene in age and had been developing under natural conditions. Probably, this reflects differences in geomorphic and lithological conditions and resultant susceptibility to both linear and sheet erosion. 
In the European loess belt, highly erodible loesses covering relatively steep hilly terrains promote easy and fast dissection of slopes and subsequent infilling of gullies by products of sheet erosion from upslope. In a small agricultural catchment in Belgium, high post-Bronze Age erosion rates have been found along with low (20-42\%) values of sediment delivery ratio (Rommens et al. 2005), which means that much sediment has been stored within the catchment filling the lowermost locations. Even lower delivery ratios were obtained for small catchments in the centre of the Russian Plain (Golosov, 1998).

Due to high erosion potential and sediment production rates, cut-and-fill erosion cycles may have rather short duration, which implies that old gullies have already been totally buried. At Hainbach (northern Bavaria), a 2-m-deep gully was formed in the 8 th century and had already been transformed into a smooth hollow by the 15-16th centuries (Dotterweich 2005). At Biesdorfer Kehlen (Brandenburg), gully heads incised and protracted during the 17-18th centuries have been totally filled by now (Schmidtchen and Bork 2003). On the other hand, in cases where newly-born gully catchments were rapidly reforested, the gullies have been conserved or filled only partially and thus survived since the Mid-Bronze Age and Roman Times (Vanwalleghem et al., 2006).

In most the above cases, phases of gullying corresponded to precipitation events or periods containing series of events of high magnitude, and strong geomorphic response was controlled by high land-use activity over the catchments. In the Satino area, the Mid-Holocene gullying occurred under undisturbed conditions and therefore may be regarded to have been governed by extreme climatic events only. Relative simultaneity may be considered to occur in formation of the Volchiy Gully and gullying in Biesdorfer Kehlen (Germany) where the oldest fill of buried head of a gully system is dated at $4,080 \pm 30 \mathrm{BP}$, or between 2,850 and 2,500 cal BC (Schmidtchen and Bork, 2003). In the Suwalki Lakeland (NE Poland), initiation of gully erosion is dated to between $3,520 \pm 70$ and 2,240 $\pm 100 \mathrm{BP}$ (Smolska 2007). It may correspond to the second erosion phase of the Volchiy and Buiniy gullies (see Fig. 7) and to the oldest dates from bottom fills of Pleistocene gullies in the Satino area that post-date the latest phase of their incision (Belyaev et al., 2005; Panin et al., 2009).

At Seedorf (Southern Germany), buried rills and gullies have been found in the bottoms of dry valleys which are thought to document rainstorms of high erosivity at about 3,000 cal years BP (Heine and Niller, 2003). That was the first episode of linear erosion here since the beginning of the Holocene. After that alternating processes of weak erosion and sedimentation occurred with no major linear erosion in the Middle Ages. In a dry valley at Nodebais (Belgium), whose catchment has undergone cultivation and sheet erosion since between 2,400 and 2,900 years ago, no gullying had been developing until the last 400-500 years when two small gullies, some $1 \mathrm{~m}$ deep, were cut into the valley bottom (Rommens et al., 2007). A 2-ka absence of gullying in the dry valley bottom in spite of favourable landscape conditions (concentration of flow from a 100-ha cultivated catchment) correlates to the decline of gully erosion at the Satino site after 2,8-3,0 cal ka BP (Panin et al. 2009, this paper). This is probably an indication of hydroclimatic conditions unfavourable for linear erosion.

Gullying in the 14-15th centuries, detected both in the Nodebais catchment (Rommens et al. 2007) and widely over Central Europe (Bork et al., 1998; Dotterweich, 2008), may be correlated to the Nabatov Gully formation at the Satino site, which has been dated between the late 13th and the early 15th centuries (Panin et al., 2009; this paper). In the Myjava Hill Land (Slovakia), gully development is reported to have followed the beginning of most intensive colonization and forest clearance in the mid-16th century (Stankoviansky, 2003). For the both gullying phases detected from historical sources, rainfalls during the Little Ice Age are considered as the triggering mechanism. Relative coincidence of erosion phases in Central Europe and central Russian Plain 
may evidence rather wide spatial coverage of hydroclimatic conditions, which governed erosion in the second half of the Holocene, though this consideration requires more confirmative data.

Importance of lithology in gully development is illustrated by the erosion history of the Frickenhauser See catchment (Bavaria), reported by Enters et al. (2008). In spite of rather steep sloping ( $80 \mathrm{~m}$ of total relief), no gullying has been detected here in the last 1,200 years since the first settlement period and the beginning of cultivation, notwithstanding a 350-fold increase of total denudation rates. The possible reason is that the catchment surface is covered by resistant to erosion regosols and cambisols developed on sandstones and limestones with almost no loesses. A similar situation was described by Klimek (2010) from the Głubczyce Plateau in the Eastern Sudetes foreland where modern linear erosion is limited by artificial terracing of cultivated slopes and shallow depth of coarse-grained regolith under thin loess cover.

\section{CONCLUSIONS}

Three of four Holocene gullies in the study area appeared and were highly active within the time span covering the Late Atlantic and most part of the Subboreal periods. Gully formation occurred probably in three short phases within 5,900-6,200 cal years, 5,200-5,500 cal years, and 4,300-4,600 cal years before present. One more phase of gully activity occurred between 3,000-3,600 cal years ago. Rise of gully erosion coincides with high floods in small and medium rivers while human impact over erosion was minimal or even not present. This provides an hydroclimatic explanation of extreme erosion - heavy rainfall events of convective or stratiform (atmospheric fronts) mechanism. The Atlantic to Subboreal transition in the centre of the Russian Plain is known for contrast temperature changes, which were favourable for extreme weather phenomena. An important additional factor of slope destabilization were forest fires. Erosional effects produced at that time have no analogs in the Holocene. Therefore, it may be thought that the Mid-Holocene was characterized by extreme precipitation events clustered into several short epochs with magnitudes probably within the highest ranks in the Holocene.

\section{ACKNOWLEDGEMENTS}

Financial support for this study was provided by the Russian Foundation for Basic Research, Project No.06-05-65218.

\section{REFERENCES}

Ananyeva, E.G. (1998), Lithological and mineralogical analysis in geomorphological and palaeogeographical studies, Moscow, Faculty of Geography MSU [in Russian].

Antonov, S.I., Danshin, A.I. and Kazmin M.A. (2005), Change in land cover and cultural landscapes in south-western part of Moscow Region, Russia, in Milanova E., Himiyama Y., Bicik I. (eds.), Understanding Land-Use and Land-Cover Change in Global and Regional Context. Science Publishers, Enfield (NH), 97-105.

Belyaev, Yu., Panin, A. and Belyaev, V. (2004) Climate-induced and local-scale erosion and sedimentation features in small catchments: Holocene history of two small valleys in Central Russia, in Belyaev, V., Golosov, V. and Walling, D. (eds.), Sediment Transfer through the Fluvial System (Proceedings of a symposium held in Moscow, August 2004), IAHS Publications, 288: 3-12.

Belyaev, Yu.R., Panin, A.V. and Belyaev, V.R. (2003), History of dry valleys in the centre of the Russian Plain: the Cholokhovskaya Balka case study, the Satino area, Vestnik Moskovskogo Universiteta, Seria 5 Geografia, 5(2003): 55-63 [in Russian].

Belyaev, V.R., Eremenko, E.A., Panin, A.V. and Belyaev, Y.R. (2005), Stages of late Holocene gully development in the central Russian Plain, International Journal of Sediment Research, 20: 224-232. 
Bolysov, S.I. and Tarzaeva, N.V. (1996), Meteorological factor of gully headcut retreat in the South-West of the Moscow Region, Geomorfologia, 4: 97-103 [in Russian].

Bork, H.-R., Bork, H., Dalchow, C., Faust, B., Piorr, H.-P. and Schatz, T. (1998), Landschaftsentwicklung in Mitteleuropa - Wirkungen des Menschen auf Landschaften, Klett-Perthes, Gotha.

Bronk Ramsey, C. (2005), OxCal Program v3.10, Oxford Radiocarbon Accelerator Unit, Oxford (UK) <http://c14.arch.ox.ac.uk/>.

Brunsden, D. and Thornes, J.B. (1979), Landscape sensitivity and change, Transactions of the Institute of British Geographers, 4(4): 403-484.

Bull, W.B. (1991), Geomorphic responses to climatic change, Oxford University Press.

Crozier, M.J. (1999), The frequency and magnitude of geomorphic processes and landform behaviour, Zeitschrift für Geomorphologie, Supplementband, 115: 35-50.

Dedkov, A.P., Mozzherin, V.I., Stupishin, A.V. and Trofimov, A.M. (1977), Climatic Geomorphology of Denudation Plains, Kazan' University Press [in Russian].

Dotterweich, M. (2005), High resolution reconstruction of a 1300 years old gully system in Northern Bavaria, Germany as a basis for modelling long term man induced landscape evolution, The Holocene, 15: 994-1005.

Dotterweich, M. (2008), The history of soil erosion and fluvial deposits in small catchments of Central Europe: deciphering the long term interaction between human and the environment - a review, Geomorphology, 101: 192-208.

Dyakonov, K.N. and Abramova, T.A. (1998), Results of palaeo-landscape research in Central Meschera Lowland, Izvestiia Russkogo Obshchestva Geograficheskogo, 130(4): 10-21 [in Russian].

Elovicheva, Ya.K., Bogdel', I. I. , Zernitskaya, V.N. and Klimanov, V.A. (1988), Climatic reconstructions of the Holocene in Byelorussia by palynological data, in Velichko, A.A. and Khotinskiy, N.A. (eds), Holocene Palaeoclimates of the European Territory of the USSR, Institute of Geography RAS, Moscow, 86-94.

Enters, D., Dörfler, W. and Zolitschka, B. (2008), Historical soil erosion and land-use change during the last two millennia recorded in lake sediments of Frickenhauser See, northern Bavaria, central Germany, The Holocene, 18: 243-254

Eremenko, E.A., Belyaev, V.R., Karevskaya, I.A. and Panin, A.V. (2005), Natural and anthropogenic factors in gully development: case study of the Uzkiy Gully, the Satino key area, Geomorfologia, 3: 52-65 [in Russian].

Golosov, V. (1998), Redistribution of sediments within small river catchments in the agricultural zone of Russia, Geomorphologie: relief, processus, environnement, 1: 53-64.

Heine, K. and Niller, H.-P. (2003), Human and climate impacts on the Holocene landscape development in southern Germany, Geographia Polonica, 76(2): 109-122.

Kashkin, A.V., Krasnov, Ju.A., Massalitina, G.A., Proshkin, O.L., Smirnov, A.S., Sorokin, A. N. and Frolov, A.S. (2006), Archaeological Map of Russia: The Kaluga Region, Institute of Archaeology, Russian Academy of Sciences, Moscow [in Russian].

Khotinskiy, N.A. (1977), The Holocene of the Northern Eurasia, Nauka, Moscow.

Khotinskiy, N.A. (1989), Discussion problems of reconstruction and correlation of the Holocene palaeoclimates, in Khotinskiy N.A. (ed.), Palaeoclimates of the Late Glacial and the Holocene, Nauka, Moscow: 12-17.

Klimek, K. (2010), Past and present interaction between the catchment and the valley floor: Upper Osoblaha basin, NE Sudetes slope and foreland, Quaternary International, 220: 112-121.

Panin, A.V. (2001), Holocene river transformation in the center of European Russia: the middle Protva River case study, Trudy Akademii Vodokhozyaistvennykh Nauk, 7: 161-185.

Panin, A. V. (2008), Chronology of Erosion in the Center of the Eastern European Plain over the Last 5000 Years, Doklady Earth Sciences, 423(8): 1324-1329.

Panin, A.V., Eremenko, E.A. and Kovda, I.V. (2011), Cut and fill erosion cycle in the Stavropol Region in the end of the Pleistocene. Part 2. Dry valleys. Regional erosion history, Geomorfologia, 2: 102-113.

Panin, A.V., Fuzeina, Yu.N. and Belyaev, V.R. (2009), Long-term development of Holocene 
and Pleistocene gullies in the Protva River basin, Central Russia, Geomorphology, 108: 71-91.

Panin, A.V., Karevskaya, I.A. (2000), Floodplain development history in the Protva River at the Satino area, Vestnik Moskovskogo Universiteta, Seria 5, Geografia, 4: 55-62 [in Russian].

Panin, A.V., Karevskaya, I.A. and Markelov, M.V. (1999), Evolution of the Yazvitsy Valley in the Protva River basin in the second half of the Holocene, Vestnik Moskovskogo Universiteta, Seria 5, Geografia, 2: 63-72 [in Russian].

Panin, A.V., Malaeva, E.M., Golosov, V.N., Ivanova, N.N. and Markelov, M.V. (1998), Geomorphic structure and Holocene history of the Berestovaya Balka, Rostov Region, Geomorfologia, 4: 70-85 [in Russian].

Phillips, J.D. (2009), Changes, perturbations, and responses in geomorphic systems, Progress in Physical Geography, 33(1): 17-30.

Reimer, P.J., Baillie, M.G.L., Bard, E., Bayliss, A., Beck, J.W., Bertrand, J.C.H., et al. (2004), IntCal04 Terrestrial Radiocarbon Age Calibration, 26-0 cal kyr BP, Radiocarbon, 46(3): 1087-1092.

Richards, K.S. (1999), The magnitude-frequency concept in fluvial geomorphology, a component of a degenerating research programme?, Zeitschrift für Geomorphologie N.F., Supplementband 118: 1-15.

Rommens, T., Verstraeten, G., Peeters, I., Poesen, J., Govers, G., Van Rompaey, A., Mauz, B., Packman, S. and Lang, A. (2007), Reconstruction of late-Holocene slope and dry valley sediment dynamics in a Belgian loess environment, The Holocene, 17: 777-788.

Rommens, T., Verstraeten, G., Poesen, J., Govers, G. and Rompaey, A.V. (2005), Soil erosion and sediment deposition in the Belgian loess belt during the Holocene: Establishing a sediment budget for a small agricultural catchment, The Holocene, 15: 1032-1043.

Schmidtchen, G. and Bork, H.-R. (2003), Changing human impact during the period of agriculture in Central Europe. The case study Biesdorfer Kehlen, Brandenburg, Germany, in Lang, A., Hennrich, K. and Dikau, R. (eds.), Long Term Hillslope and Fluvial System Modelling - Concepts and Case Studies from the Rhine River Catchment, Lecture Notes in Earth Sciences, 101, Springer-Verlag, Berlin: 183-200.

Schmitt, A., Rodzik, J., Zglobicki, W., Russock, Ch., Dotterweich, M. and Bork, H.-R. (2006), Time and scale of gully erosion in the Jedliczny Dol gully system, southeast Poland, Catena, 68: 124-132.

Schmitt, A., Zgłobicki, W., Schmidtchen, G., Rodzik, J., Dotterweich, M., Zamhöfer, S. and Bork, H.-R. (2005), Phases of gully erosion in the Kazimierz Dolny area (case study: Doty Podmularskie, SE Poland), in Rejman, J. and Zglobicki, W. (eds.), Human Impact on Sensitive Geosystems, Maria Curie-Sklodowska University Press, Lublin: 121-128.

Smolska, E. (2007), Development of gullies and sediment fans in last-glacial areas on the example of the Suwalki Lakeland (NE Poland), Catena, 71: 122-131.

Stankoviansky, M. (2003), Historical evolution of permanent gullies in the Myjava Hill Land, Slovakia, Catena, 51: 223-239.

Starkel, L. (1998), Frequency of extreme hydroclimatically induced events as a key to understanding environmental changes in the Holocene, in Issar, A.S. and Brown, N. (eds.), Water, environment and society in times of climatic change, Kluwer Academic Publishers, Dordrecht, Netherlands: 273-288.

Starkel, L. (2000), Heavy rains and floods in Europe during last millennium, in Obrębska-Starkel, B. (ed.), Reconstructions of climate and its modeling, Prace geografic$z n e, 107$, Institute of Geography of the Jagiellonian University, Cracow: 55-62.

Starkel, L. (2005), Role of climatic and anthropogenic factors accelerating soil erosion and fluvial activity in Central Europe, Studia Quaternaria, 22: 27-33.

Starkel, L. (2006), Clusterings of extreme rainfalls and evolution of fluvial systems in the Holocene, Studia Quaternaria, 23: 23-28.

Starkel, L. (2007), The diversity of fluvial system response to the Holocene hydrological changes using the Vistula River catchment as an example, Annales Societatis Geologorum Poloniae, 77: 193-205.

Sudakova, N.G., Ananyeva, E.G., Glushahkova, N.I. and Nemtsova, G.M. (1977), Lithology of 
Quaternary deposits in the Satino area: results of the complex study, in Rychagov, G.I. (ed.), Materialy Geographicheskikh Issledovaniy Satinskogo Uchebnogo Poligona. Issue 2, Moscow, VINITI: 2-33.

Tarasov, P.E., Gunova, V.S. and Uspenskaya, O.N. (1997), Lake levels of the Volga catchment as indicators of Holocene climate changes, Vestnik Moskovskogo Universiteta, Seria 5, Geografia, 3: 36-41 [in Russian].

Vanwalleghem, T., Bork, H.-R., Poesen, J., Dotterweich, M., Schmidtchen, G., Deckers, J., Scheers, S. and Martens, M. (2006), Prehistoric and Roman gullying in the European loess belt: a case study from central Belgium, The Holocene, 16: 393-401.

Velichko, A.A., Klimanov, V.A. and Belyaev, A.V. (1988), Estimation of the Volga River runoff and the Caspian Sea water balance during the optimal phases of the Mikulian (Eemian) and the Holocene, Izvestia AN SSSR, Seria Geografia, 1: 27-37.

Viles, H.A. and Goudie, A.S. (2003), Interannual, decadal and multidecadal scale climatic variability and geomorphology, Earth-Science Reviews, 61(1-2): 105-131.

Vlasov, M.V. (2005), Holocene river morphodynamics in the center of the Russian Plain. Unpublished PhD Thesis, Faculty of Geography, Moscow State University [in Russian].

Wolman, M.G. and Miller, J.P. (1960), Magnitude and frequency of forces in geomorphic processes, Journal of Geology, 68: 54-74.

Zorina, E.F., Kosov, B.F. and Prokhorova, S.D. (1975), Accounting for the anthropogenic factor in development of gully net in the steppe and forest-steppe regions of the USSR European part, Vestnik Moskovskogo Universiteta, Seria 5, Geografia, 6: 51-57 [in Russian].

Zygmunt, E. (2004), Archaeological and radiocarbon dating of alluvial fans as an indicator of prehistoric colonisation of the Glubczyce Plateau (Southwestern Poland), Geochronometria, 23: 101-107.

Paper first received: March 2011

In final form: June 2011 